\title{
Assessment of Stunting Status and Stunting Prevention Efforts in Toddlers in Penajam District, North Penajam Paser Regency
}

\author{
Ruminem, and Mayusef Sukmana ${ }^{\text {a) }}$ \\ Program Studi Diploma III Keperawatan Fakultas Kedokteran Universitas Mulawarman, Samarinda, \\ Indonesia \\ a)Corresponding Author: 200801sukmana@gmail.com
}

\begin{abstract}
North Penajam Paser Regency (PPU) is one of the 100 priority districts/cities for stunting intervention in Indonesia. The prevalence of stunting in PPU Regency is $27 \%$, while the prevalence in East Kalimantan is $28.3 \%$, and nationally, $36.4 \%$. Stunting has an impact on impaired brain growth, physical growth, and development. The purpose of community service is to analyze the characteristics of stunting toddlers and stunting prevention through posyandu activities. The method of implementing descriptive-analytic through secondary data collection activities for stunted toddlers is described. Posyandu activities for toddlers through health checks, providing nutrition education to toddlers in the villages of Penajam, Gunung Steleng, Nipah Nipah, and Nenang. Literature study on the prevention of stunting under five by the local government of PPU Regency. The results showed that there were 92 stunting toddlers, 53 boys, and 39 girls, with 68 short toddlers and 24 very short toddlers, most of whom were $>24-60$ months old, i.e. 59 toddlers. Stunting prevention includes health checks for children under five, education on stunting prevention at posyandu and strengthening of stunting prevention/control policies with Regent Regulations. More optimal efforts are needed in implementing the Regent's regulation for the prevention of stunting under five.
\end{abstract}

Keywords: stunting, toddlers, nutrition, posyandu

\section{INTRODUCTION}

The nutritional status of children under five years of age is a significant health indicator because toddlers are a group that is vulnerable to nutritional problems and diseases. Underweight and wasting indicate acute malnutrition. While stunting is a condition of failure to grow in children under five due to chronic malnutrition so that children are too short for their age (Sudikno, 2019). Stunting or short toddlers are toddlers with chronic nutritional problems who have nutritional status based on length or height according to toddler age compared to the 2005 WHO-MGRS (Multicentre Growth Reference Study) standard, which has a z-score value of more petite than -2SD. If the z-score is more minor than $-3 \mathrm{SD}$, it is categorized as a very short toddler (Hardhana et al., 2015).

The incidence of short toddlers, commonly referred to as stunting is one of the nutritional problems experienced by toddlers today. In $2017,22.2 \%$ or around 150.8 million children under five in the world experienced stunting. However, this figure has decreased compared to the stunting rate in 2000 , which was $32.6 \%$ (Kemenkes RI, 2018a). According to WHO, Stunting is one of the Sustainable Development Goals (SDGs) targets, which is included in the 2nd sustainable development goal, namely eliminating hunger and all forms of malnutrition by 2030 and achieving food security. The target set is to reduce the stunting rate to $40 \%$ by 2025 (Pusat Data dan Informasi Kemenkes RI, 2018).

Data on the prevalence of stunting for children under five years of age collected by the World Health Organization (WHO) released in 2018 stated that Indonesia is the third country with the highest prevalence in the South-East Asian Region after Timor Leste (50.5\%) and India (38.4\%), and Indonesia by $36.4 \%$ (Kemenkes RI, 2018a). The stunting prevalence rate in Indonesia is still above $20 \%$, meaning that it has not reached the WHO target below $20 \%$. The Study on the Nutritional Status of Indonesian Toddlers (SSGBI) conducted in 2019 showed that the prevalence of stunting in children 0-59 (toddlers) months in Indonesia in 2019 was $27.3 \%$, the 
prevalence of stunting in East Kalimantan was 28.3\%, and the prevalence of stunting in PPU Regency of $27.0 \%$ ranks 7 th out of 10 cities/districts of stunting prevalence in East Kalimantan(Sudikno, 2019). PPU District is also included in the list of 100 priority districts/cities for stunting interventions in Indonesia (Tim Nasional Percepatan Penanggulangan Kemiskinan, 2017).

The cause of stunting is low nutritional intake in the first 1,000 days of life, from fetus to baby aged two years(Kemenkes RI, 2018b). According to Darteh et al., 2014, (Tanzil \& Hafriani, 2021) that the causes of stunting consist of essential factors such as the mother's economy and education, intermediate factors, namely the number of family members, maternal height, maternal age, and the number of maternal children and proximal factors include giving Exclusive breastfeeding, child age and LBW.

The impact of stunting and impaired physical growth of children also affects the growth of the toddler's brain. Children with stunting have a low IQ. Stunting has a lifelong impact on children. Stunting raises concerns about children's development because of its long-term effects(Tanzil \& Hafriani, 2021). Stunting can be prevented, among others, by fulfilling pregnant women's nutritional needs, exclusive breastfeeding for six months then followed by complementary feeding. Parents are also expected to bring their toddlers regularly to the Posyandu, meet the needs of clean water, improve sanitation facilities, and maintain environmental cleanliness(Kemenkes RI, 2018b).

The purpose of this community service is to analyze the characteristics of stunting toddlers, including the number of stunting toddlers, the stunting category based on the standard length or height of the child, the stunting category based on age and describe the countermeasures that the PPU Regency government has carried out with 47 Unmul KKN students.

\section{METHOD}

The implementation of this community service uses a descriptive-analytical method through secondary data collection activities originating from health cadres of posyandu in the villages of Penajam, Nipah-Nipah, Gunung Seteleng and Nenang. The data collection period is July 14, 2021, to August 14, 2021. Analyze the status of stunting under five. Conducting health checks, providing nutritious food and counselling on stunting prevention carried out by health workers, posyandu cadres and KKN 47 students at Mulawarman University and study of stunting prevention and control literature by the PPU Regency government.

\section{RESULTS}

Based on the results of secondary data collection at the Posyandu for toddlers obtained in four villages, including the villages of Penajam, Gunung Seteleng, Nenang and Nipah-Nipah in the PPU district, the number of children under five who experienced stunting was 92 people.

The characteristics of children under five who experience stunting based on the number of stunting in each kelurahan, age, gender and stunting category are shown in the table below:

Table 1. Characteristics of stunting under five by number, age of toddler, gender and category of stunting in Penajam, Gunung Seteleng and Nenang and Nipah-Nipah subdistricts. PPU Year 2021. $\mathrm{N}=92$.

\begin{tabular}{llcc}
\hline Characteristics & Category & $\mathrm{n}$ & Amount \\
\hline Ward & Penajam & 15 & 16,0 \\
& Gunung Seteleng & 26 & 28,3 \\
& Nenang & 25 & 27,4 \\
\multirow{2}{*}{ Age Toddlers } & Nipah-Nipah & 26 & 28,3 \\
& $0-24$ month & 33 & 35,9 \\
Sex & $>24-60$ month & 59 & 64,1 \\
& Male & 53 & 57,6 \\
\hline
\end{tabular}




\begin{tabular}{llll}
\hline Stunting Category & Very short (<-3 SD ) & 24 & 26,1 \\
& Short (-3 SD sd <-2 SD) & 68 & 73,9 \\
\hline
\end{tabular}

From table 1 above, it can be seen that the proportion of children under five who experience stunting in Gunung Seteleng and Nipah-Nipah sub-districts is 26 each (28.3\%), in Nenang subdistrict there are 25 (27.4\%), and the number of children under five who experienced the least stunting was in Penajam village, which was 15 children (16.0\%). More toddlers aged $>24-60$ months amounted to 59 toddlers (64\%), and aged 0-24 months who experienced stunting were 33 toddlers (36\%). The gender that more males experience stunting is $53(58 \%)$, and women are 39 children under five (42\%). In comparison, the stunting category experienced by toddlers was the majority of the short category of 68 toddlers $(74 \%)$ and the very short stunting category of 24 toddlers (26\%).

Table 2. Characteristics of stunting categories based on the age of toddlers in Penajam village, Gunung Seteleng. Nenang and Nipah-Nipah Kab. PPU Year 2021. N=92

\begin{tabular}{lcccc}
\hline \multirow{2}{*}{ Age Toddlers } & \multicolumn{4}{c}{ Stunting Category (PB/U) } \\
& $\mathrm{n}$ & $\%$ & $\mathrm{n}$ & Short \\
\hline $0-24$ month & 8 & 24,7 & 25 & $\%$ \\
$>24-60$ month & 16 & 27,1 & 43 & 75,8 \\
\hline
\end{tabular}

Based on table 2 above, it can be seen that 33 stunting toddlers aged 0-24 months experienced more short categories as many as 25 toddlers $(75.8 \%)$ and toddlers aged $>24-60$ months also experienced more short categories by 43 toddlers $(72.9 \%)$ while the very short category was 16 toddlers (27.1\%).

Table 3. Characteristics of stunting under-fives by gender in the villages of Penajam, Gunung Seteleng, Nenang and Nipah-Nipah Kab. PPU Year 2021. N=92

\begin{tabular}{lcccc} 
& \multirow{4}{*}{ Sex } & \multicolumn{5}{c}{ Stunting Category (PB/U) } \\
& $\mathrm{n}$ & $\%$ & $\mathrm{n}$ & Short \\
& 11 & 20,8 & 42 & $\%$ \\
\hline Male & 13 & 33,3 & 26 & 69,2 \\
Female & & & &
\end{tabular}

Table 3 shows that male toddlers who experience stunting are more in the short category, namely 42 toddlers (79.2\%) and the very short category as many as 11 toddlers (20.8\%). Likewise, female children under five have more short stunting categories than concise categories, namely 26 toddlers $(66.7 \%)$.

Table 4. Distribution of the characteristics of stunting under five by age, gender and age in the villages of Penajam, Gunung Seteleng, Nenang and Nipah-Nipah, PPU Year 2021. N= 92

\begin{tabular}{|c|c|c|c|c|c|c|c|}
\hline \multirow[t]{2}{*}{ Ward } & \multirow{2}{*}{$\begin{array}{l}\text { Number } \\
\text { of } \\
\text { Stunting } \\
\text { Toddlers }\end{array}$} & \multicolumn{2}{|c|}{ Age } & \multicolumn{2}{|c|}{ Sex } & \multicolumn{2}{|c|}{ Stunting Category } \\
\hline & & $0-24$ & $>24-60$ & Male & Female & Very Short & Short \\
\hline Penajam & 15 & $3(9,1 \%)$ & $12(20,3 \%)$ & $7(13,2 \%)$ & $8(21,1 \%)$ & $8(33,3 \%)$ & $7(10,3 \%)$ \\
\hline Gn. Seteleng & 26 & $\begin{array}{c}11 \\
(33,3 \%)\end{array}$ & $15(25,4 \%)$ & $20(37,8 \%)$ & $6(15,3 \%)$ & $2(8,4 \%)$ & $24(35,3 \%)$ \\
\hline Nenang & 25 & $\begin{array}{c}11(33 \\
, 3 \%)\end{array}$ & $14(23,7 \%)$ & $12(22,6 \%)$ & $13(33,0 \%)$ & 6 (25\%) & 19 (27.9\%) \\
\hline Nipah-Nipah & 26 & $8(24,3 \%)$ & $18(30,6 \%)$ & $14(26,4 \%)$ & $12(30,6 \%)$ & $8(33,3 \%)$ & $18(26,5 \%)$ \\
\hline Jumlah & 92 & 33 (100\%) & $59(100 \%)$ & $53(100 \%)$ & $39(100 \%)$ & $24(100 \%)$ & 68(100\%) \\
\hline
\end{tabular}

Based on table 4 above, it can be seen that of the four urban villages based on the age of toddlers who experience stunting, at will, most of them are aged $>24-60$ months, the majority are in Nipah Nipah, namely 24 toddlers (37\%). The gender of toddlers experiencing stunting, in Gunung Seteleng and Nipah-Nipah, was more male, namely 20 toddlers (38\%) and 14 toddlers 
(26\%), while in Penajam and Nenang, there were more female genders, namely respectively eight toddlers (21\%) and 13 toddlers (33\%). The stunting category in the four sub-districts that experienced the very short category was the most in Penajam and Nipah Nipah, each with eight toddlers (33.3\%) and the Ward with the least number of very short stunting toddlers, namely Gunung Seteleng with only two toddlers (8.4\%). While stunting under five in the short category, the highest number was in Gunung Seteleng sub-district, namely 24 toddlers (35.3\%) and then Nenang as many as 19 (27.9\%) and the lowest was in Penajam, namely seven toddlers (10.3\%).

\section{DISCUSSION}

Toddlers who experienced stunting in Penajam, Gunung Seteleng, Nenang and Nipah-Nipah sub-districts were 92 toddlers, from four villages the number of toddlers experiencing stunting was Gunung Seteleng village 26 (28.3\%) and Nipah Nipah village 26 (28.3\%). According to Aridiyah, the factors that influence the incidence of stunting in children and toddlers in urban and rural areas are maternal education, family income, mother's knowledge of nutrition, exclusive breastfeeding, and age of age complementary feeding, zinc adequacy level, and iron, a history of infectious diseases and genetic factors.(Aridiyah et al., 2015)

The age of toddlers experiencing stunting in the four urban villages is classified into two categories 0-24 months and >24-60 months based on the standard length or height of children according to age (PB/U) having a Z-score of less than -2 SD(Permenkes RI, 2020) Toddlers who experienced stunting from 92 more toddlers aged 24-60 months, namely 59 toddlers $(64.1 \%)$, while those aged 0-24 months were 33 toddlers (35.9\%). The group of toddlers aged 24 months and over is more at risk of suffering from stunting than toddlers under one year of age because toddlers aged 0-23 months have the protection of breast milk obtained. Stunting in toddlers will harm the next life that is difficult to repair (Haile et al., 2016). Based on the age of toddlers 0-60 months, it can also be seen that toddlers who experience stunting in the four urban villages are mainly in the short category as many as 68 toddlers $(73.9 \%)$, while the remaining 24 toddlers $(26.1 \%)$ were in the very short category. The measurement of the stunting category follows the standard body length according to age (PB/U) for boys and girls, and the very short stunting category is one of the most in the Penajam sub-district, namely from 15 toddlers eight toddlers are in the very short category. The causes of stunting in toddlers are due to low access to nutritious food, low intake of vitamins and minerals, and poor food diversity and animal protein sources. In addition, the cause of maternal factors and poor parenting, especially in the behaviour and practice of feeding children, is also the cause of stunting if the mother does not provide adequate and good nutrition(Kemenkes RI, 2018b). According to Arnold Wayong, Head of the PPU District Office, the causes of stunting in sharpening include poverty, parenting and poor sanitation(M. Ghopar, 2020).

Based on gender, more boys under five experience stunting, namely $53(57.6 \%)$ and girls as many as 27 toddlers (42.4\%), most of which are in the Gunung Seteleng sub-district, namely 20 toddlers (37.8\%). This is under the results of Riskesdas 2013 that the prevalence of stunting was found to be higher in boys (38.1\%) than girls (36.2\%)(Badan Penelitian dan Pengembangan Kesehatan, 2013). However, according to (Pujiningsih \& Muryanto, 2021) that gender is not related to the incidence of stunting. The possible cause is that there is no difference in toddlers' speed and achievement of growth between boys and girls. These differences will begin to appear when entering adolescence. Namely, girls will first experience an increase in the speed of growth. This causes men and women to have the same risk of experiencing stunting. Based on the gender characteristics, data showed that from 24 stunting toddlers in the very short category (<-3 SD ), more were girls, namely 13 toddlers (33.3\%), while 68 toddlers were in the short stunting category (-3 SD <-2 SD). SD) is more common in boys, namely 42 toddlers (79.2\%).

Considering that the prevalence of stunting is relatively high, it negatively impacts children's growth and affects the quality of human beings in the future. According to (Kemenkes RI, 2018b) children affected by stunting can have their brain development stunted after an adult child's intelligence, and educational performance is not optimal, and they are at risk for metabolic 
diseases. So it is essential to make efforts to prevent the risk of stunting in children. Steps to prevent stunting include: meeting the nutritional needs of pregnant women, exclusive breastfeeding until the baby is six months old, accompanying exclusive breastfeeding with healthy complementary foods when the baby is six months old, continuing to monitor the child's growth and development regularly at the posyandu, maintaining a clean environment because children are very vulnerable to disease(Kemenkes RI, 2019)(Kemenkes RI, 2018a)

Prevention and control of stunting in four urban villages are through health checks, including weighing and measuring body length, anthropometric measurements, administering vaccines, and nutrition education conducted by KKN 47 Mulawarman University students and health workers posyandu health cadres. Increased educational counselling and information on the risk of editing and its management are needed because many residents have not been exposed to treatment during pregnancy, birth and infancy(Widaryanti et al., 2021). Students and health cadres provide nutrition education using the media in the Maternal and Child Health Book. According to (Mursalim, 2018) (Sari et al., 2021) educational media is crucial as a communication tool that makes it easier for mothers to get health information for their children, easy to carry and easy to open.

The PPU Regency Government takes stunting prevention and control measures by issuing the PPU Regency Regent Regulation on the Acceleration of Stunting Reduction and Prevention (Peraturan Bupati, 2019). According to the PPU Regent, stunting is a national development agenda, PPU district is one of the priority districts out of 100 districts/cities in Indonesia. The key to preventing and handling stunting cases, especially in the First 1,000 Days of Life (HPK), is monitoring pregnant women and children under two years of age to specific nutrition and sensitive interventions. This intervention is carried out by all sectors where the health sector is the leading sector. The non-health sector strongly influences the program's success, with the proportion of support reaching 70 per cent. This support includes the development of sanitation, clean water, provision of safe, nutritious food, good understanding, and concern for each individual and community to optimize their role in stunting prevention efforts(Kusnadi, 2021) The interview results in a public dialogue zooming welcoming the State Capital on July 27, 2021; the Deputy Regent of PPU Regency said that education on healthy eating patterns had been carried out to coastal residents who produce fish as the primary source of protein.

\section{CONCLUSIONS AND RECOMMENDATIONS}

The profile of stunting toddlers in Penajam, Gunung Seteleng, Nenang and Nipah-Nipah, PPU Regency is as follows: 92 toddlers who experience stunting, Penajam subdistrict 15 toddlers, Gunung Seteleng 26 toddlers, Nipah-Nipah 26 toddlers, Nenang 25 toddlers. The short category is 68 toddlers $(73.9 \%)$, and the very short category is $24(26 \%)$. Based on age, more than $24-60$ months, namely 59 toddlers (64.1\%). There are more male sex, namely 53 (57.6\%). Stunting prevention includes health checks for children under five, education on stunting prevention and nutrition at the posyandu and issuing the PPU Regency Regent Regulation. Tackling stunting requires more optimal efforts in each health and non-health sector.

\section{ACKNOWLEDGMENTS}

The authors would like to thank the Research and Community Service Institute of Mulawarman University for their permission, direction, financial support in carrying out community service activities and assisting Unmul $47 \mathrm{KKN}$ students in 2021 who work in Penajam, Gunung Seteleng, Nenang and Nipah Nipah Villages.

\section{REFERENCES}

Aridiyah, F. O., Rohmawati, N., \& Ririanty, M. (2015). Faktor-faktor yang Mempengaruhi Kejadian Stunting pada Anak Balita di Wilayah Pedesaan dan Perkotaan. E-Jurnal Pustaka Kesehatan, Vol. 3 (no. 1) Januari 2015, 3(1), 163-170. https://doi.org/10.1007/s11746-0132339-4

Badan Penelitian dan Pengembangan Kesehatan. (2013). Riset Kesehatan Dasar 2013. In 
Kementerian Kesehatan RI (Vol. 7, Issue 5). https://doi.org/10.1517/13543784.7.5.803

Hardhana, B., Budiono, C. S., Kurniasih, N., Susanti, M. I., Manullang, E. V, Pangribowo, S., Harpini, A., Aprianda, R., Sakti, E. S., Susetyoaji, E., Habibi, H. A., \& Sari, D. M. (2015). Data \& Informasi 2015 "Profil Kesehatan Indonesia."

Kemenkes RI. (2018a). Buletin Stunting. Kementerian Kesehatan RI, 1(1), 1-48.

Kemenkes RI. (2018b). Hasil Riset Kesehatan Dasar Tahun 2018. Kementrian Kesehatan RI, 53(9), 1689-1699.

Kemenkes RI. (2019). Cegah Stunting. Direktorat Promkes Dan Pemberdayaan Masyarakat. https://promkes.kemkes.go.id/pencegahan-stunting

Kusnadi. (2021). AGM ajak Komitmen bersama dalam Penurunan dan Pencegahan Stunting di PPU. InfoPublik Portal Berita Info Publik. https://infopublik.id/kategori/nusantara/537702/agm-ajak-komitmen-bersama-dalampenurunan-dan-pencegahan-stunting-di-ppu

M. Ghopar. (2020). Penanganan stunting libatkan lintas sektor. Antara Kaltim. https://kaltim.antaranews.com/berita/84238/penanganan-stunting-di-penajam-libatkanlintas-sektor

Mursalim. (2018). Pemeriksaan Angka Lempeng Total Bakteri pada Minuman Sari Kedelai yang diperjualbelikan di Kecamatan Manggala Kota Makassar. Jurnal Media Analis Kesehatan, 1(1).

Peraturan Bupati. (2019). Peraturan Bupati Penajam Paser Utara Nomor 34 Tahun 2019 Tentang Percepatan Penurunan dan Pencegahan Stunting (pp. 1-21).

Permenkes RI. (2020). Peraturan Menteri Kesehatan Republik Indonesia Nomor 2 Tahun 2020 Tentang Standar Antropometri Anak (pp. 1-78).

Pujiningsih, R., \& Muryanto, S. (2021). Peran Media Sosial Sebagai Media Pemasaran dan Branding Bisnis UMKM di Era Pandemi Covid-19 di Dusun Ngloran RT 01 RW 02, Desa Pilangpayung, Kecamatan Toroh, Kabupaten Grobogan. Senyum Boyolali, 2(1), 21-25. https://doi.org/10.36596/sb.v2i1.526

Pusat Data dan Informasi Kemenkes RI. (2018). Situasi Balita Pendek (Stunting) di Indonesia, Buletin Jendela Data dan Informasi Kesehatan, Jakarta. In Kementerian Kesehatan RI (Vol. 301, Issue 5).

Sari, I. P., Trisnaini, I., Ardillah, Y., \& Sulistiawati, S. (2021). Buku Saku Pencegahan Stunting sebagai Alternatif Media dalam Meningkatkan Pengetahuan Ibu. Dinamisia: Jurnal $\begin{array}{llll}\text { Pengabdian Kepada } \quad \text { Masyarakat, } & \text { 500-304. }\end{array}$ https://doi.org/10.31849/dinamisia.v5i2.4669

Sudikno. (2019). Laporan Akhir penelitian Studi Status Gizi Balita di Indonesia Tahun 2019, Puslitbang UKM BPPK Kemenkes RI.

Tanzil, L., \& Hafriani, H. (2021). Faktor-Faktor Yang Mempengaruhi Terjadinya Stunting Pada Balita Usia 24-59 Bulan. Jurnal Kebidanan Malahayati, 7(1), 25-31. https://doi.org/10.33024/jkm.v7i1.3390

Tim Nasional Percepatan Penanggulangan Kemiskinan. (2017). 100 Kabupaten/Kota Prioritas Untuk Intervensi Anak Kerdil (Stunting) (Cetakan Pe, Vol. 1). Sekretariat Wakil Presiden Republik Indonesia.

Widaryanti, R., Maydianasari, L., Maranressy, M., Studi, P., Program, K., Fakultas, S., Kesehatan, I., \& Respati, U. (2021). Cegah Stunting Pada Masa Pandemi Covid-19 dengan Pembentukan Srikandi PMBA. DINAMISIA: Jurnal Pengabdian Kepada Masyarakat, 5(4), 979-985. 


\section{APPENDIX}

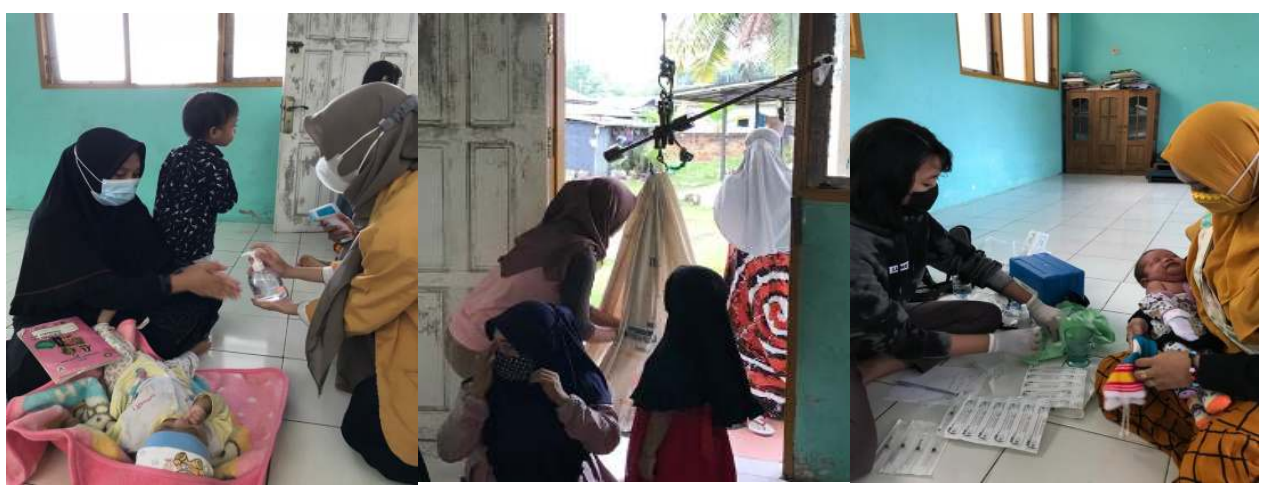

Figure 1. Medical examination of stunting 